\title{
Reassessing Relationships in Consumer Markets: Emotion, Cognition, and Consumer Relationship Intention
}

\author{
TERESA FERNANDES and JOÃO PROENÇA \\ Faculty of Economics, University of Porto, Porto, Portugal
}

\begin{abstract}
This article shows the importance of consumer relationship intention and its cognitive and emotional motivations in the development of a relational approach in buyer-seller relationships in business-to-consumer settings. The article presents empirical research that used a cross-sectional survey of 222 consumers followed by discriminant analysis to bighlight the fact that different relationships may exist in consumer markets. We found that cognitionbased motivations explain functional relationship outcomes and that emotion-based motivations explain bigher forms of dedication to the provider, such as altruism, switching intentions, and acquiescence. The article shows that consumer proneness and motivations are bighly significant in discriminating relationships.
\end{abstract}

KEYWORDS consumer markets, relationship marketing, relationships, service markets

In the early to mid-1990s, relationship marketing (RM) became "the hot topic of the marketing discipline" (Möller \& Halinen, 2000, p. 29). Often described as the emperor's new clothes (Egan \& Harker, 2006), RM began to dominate the marketing agenda. However, as the dust begins to settle, questions are being asked about how much of RM is reality and how much is pure rhetoric (Agariya \& Singh, 2011; Shrivastava \& Kale, 2003). RM practices may not be ubiquitous and may suffer from considerable shortcomings in business-to-consumer (B2C) markets, in which the majority of relationships are not close and long term but rather distant and discrete (O'Malley \& Tynan, 2000). Also, the RM literature in consumer markets tends to emphasize

Address correspondence to Dr. Teresa Fernandes, Faculty of Economics, University of Porto, Rua Dr. Roberto Frias, s/n, 4200-464 Porto, Portugal. E-mail: tfernandes@fep.up.pt 
the seller's point of view to the neglect of the buyer's perspective. Developing on previous findings (Fernandes \& Proença, 2008), the aim of this article is to explore buyer-seller relationships in B2C markets, considering the consumer's point of view. We propose a framework to distinguish relationships according to a consumer's emotion- or cognition-based motivations. This framework is empirically examined through a cross-sectional consumer survey and discriminant analysis. We conclude that consumer proneness and motivations are highly significant in discriminating relationship types and that the focus on the monotypic close and long-term relationships in consumer markets may be limited.

\section{RELATIONSHIPS IN CONSUMER MARKETS}

Relationships both drive and are driven by the context in which they take place (Egan, 2003; Fournier, Dobscha, \& Mick, 1998; Möller \& Halinen, 2000). Grönroos (1991) stated that the marketing strategies available may be seen as a continuum between a relationship-oriented strategy and a transactionoriented strategy and that one orientation makes more sense than another depending on the circumstances. Thus, RM practices and strategies may not be effective in every situation or context.

The relational perspective was initially presented in the literature as an alternative to mainstream marketing, more suited to marketing in interorganizational situations in which markets were heterogeneous, buyers and sellers were both active, and interaction and relationships were important. Social exchange theory and relational contracting were applied to understand relationships (Hansen, 2012). Based on these theories, the interaction approach (Ford, 2004) considers that a relationship implies that both parties should be positively committed. Researchers compared a marketing relationship to a marriage that is exclusive, that is enduring, and that forsakes all other relationships (Tynan, 1997). Yet those findings and constructs from business markets were uncritically imported and applied by marketers to consumer markets (Bejou, 1997; Egan, 2003), and this can present considerable barriers (Egan \& Harker, 2006; Zolkiewski, 2004). The differences between business and consumer domains have to do with switching costs, the availability of alternatives, the type and frequency of interactions, the level of interdependency, underlying motives, relative size, and the overall importance buyers and sellers attach to relationships. Moreover, the sheer size of the market, the lack of consumer interest in relationships, and the persistence of aggressive promotion strategies all make for problems.

These differences affect the patterns of buyer-seller relationships in both markets. The majority of consumer relationships are not close and long term but distant and discrete (O'Malley \& Tynan, 2000). The marriage analogy is inappropriate in consumer markets, in which a commitment may 
be attractive to the supplier, but not to the buyer, who incurs the opportunity cost of fidelity (Szmigin \& Bourne, 1998). When the drawbacks of engaging in a relationship (e.g., loss of privacy, upkeep, commitment) are perceived as too high by consumers, consumers may avoid relationship formation and engagement; this is called a "relationship hindrance" (Noble \& Phillips, 2004), a "relationship burden" (Hakansson \& Snehota, 2002), or "the dark side of long-term relationships" (Grayson \& Ambler, 1999). Consumers may be interested in developing relationships with some suppliers and not with others (Pels, 1999). Customers can even have simultaneous relationships with several providers and, over time, drop some and add others. In fact, consumers are generally "promiscuous" in the relationships they establish (Szmigin \& Bourne, 1998). Given this scenario, a supplier should aim not to be a marriage partner but a preferred friend.

Hence, the development of RM practices in consumer markets seems to suffer from several shortcomings (Grayson \& Ambler, 1999; Hennig-Thurau, Paul, Gremler, Gwinner, \& Weitz, 2009; Pressey \& Mathews, 2000; Shrivastava \& Kale, 2003). Several scholars have recognized that different types of customer-firm relationships exist (Dwyer, Shurr, \& Oh, 1987; Fournier, 1998; Hellén, Gummerus, Grönroos, \& Sääksjärvi, 2007) beyond the prototypical monotonic long-term relationship. Relationships may be better portrayed by varying degrees of relational complexity (Möller \& Halinen, 2000) and perhaps sometimes are neither better or worse but just what they are (Palmer, 2007). It is thus important to reconsider what a relationship in consumer markets means.

However, according to Bagozzi (1995), in consumer markets, relationship definition constitutes a glaring omission. The term relationship is often used to underpin a supplier's marketing activities based on the assumption that a relationship can be formed with any customer, in any situation (Blois, 1997). A review of the literature on RM still reveals a definitive tendency to focus on the seller's perspective to the neglect of the buyer's perspective (Barnes, 1997; Sheth \& Parvatiyar, 1995). However, it must be questioned whether a relationship exists when the exchange has been examined from the point of view of only one party to the exchange (Blois, 2003). If in some situations consumers are not even aware they are participating, can this be called a relationship? Not every exchange has the potential to grow into one, and both sides of any transaction or relationship affect its nature. Relationship studies that only examine the views of one party can at best only provide a "partial picture" (Blois, 2003, p. 90). Customers' interests should be at the heart of the equation. A relationship can only be said to truly exist if and when the customer says there is one, and not when the firm suggests it (Egan, 2000). This "consumer recognition," "psychological predisposition," "relationship intention," or "relationship proneness" (Christy, Oliver, \& Penn, 1996; De Wulf, Odekerken-Schröder, \& Iacobucci, 2001; Kumar, Bohling, \& Ladda, 2003; Parish \& Holloway, 2010) may be the prime driver to a 
relational approach. Not all customers wish to engage in close relationships, nor are they willing participants in RM strategies or equally receptive (Bendapudi \& Berry, 1997; Hennig-Thurau, Gwinner, \& Gremler, 2002). Yet few authors have explored why consumers may be reluctant to form relationships with retailers (Noble \& Phillips, 2004), and the buyer's perspective remains the blind spot of relationships in consumer markets (Pels, 1999).

\section{RELATIONSHIP INTENTION, AFFECT, AND COGNITION}

Considering the consumer's point of view, we define relationship intention as the willingness to establish a relationship with a firm in a free and deliberate way. This conceptualization stems from social psychology, in which intention has been viewed as the willingness to continue a course of action or activity, such as maintaining a relationship (Wetzels, de Ruyter, \& Birgelen, 1998). According to attitude research (Fishbein \& Ajzen, 1975), a person's behavior is determined by his or her intention to perform it. The attitudinal dimension includes cognitive, affective, and conative processes that strongly impact overt behavior, which may be impossible to understand and difficult to predict without knowledge of these processes. The affective component refers to emotions, feelings, and drives associated with an attitude object, whereas the cognitive component addresses beliefs, judgments, and thoughts associated with the object (Breckler, 1984; Breckler \& Wiggins, 1989). Being a conative variable, intentions should come to mediate the relationship between affective, cognitive, and behavioral constructs (Ajzen \& Fishbein, 1980). In fact, self-reported behaviors and stated intentions to respond have frequently been treated as dependent effects of affective and/or cognitive variables (e.g., Rogers \& Thistlethwaite, 1970; Warner \& DeFleur, 1969). Intentions would be at a lower level of abstraction (i.e., closer to overt behavior) than the cognitions and affective feelings on which they are based. Cognitions and affective feelings would form a predisposition to respond in a consistently favorable or unfavorable manner with respect to a given object (Fishbein \& Ajzen, 1975), and intention focuses on the willingness to act on that given predisposition or a "readiness to act" (Oliver, 1999). Intention is the personal, deliberate, goal-oriented, proactive aspect of behavior (Emmons, 1986) and is closely related to the concept of intrinsic motivation and volition. Behavioral intentions, in turn, lead to overt behaviors (Bagozzi \& Burnkrant, 1979).

There is evidence that cognition and affective components of attitude can be distinguished from each other (Breckler, 1984; Breckler \& Wiggins, 1989). Cognition is a more instrumental component, which refers to a more calculative consideration of the extent to which performing a behavior would be advantageous (i.e., the expected utility of the behavior; Breckler \& Wiggins, 1989; French et al., 2005). Emotion is a more affective component, 
which refers to anticipated feelings toward performing the behavior (French et al., 2005; Godin, 1987; Trafimow \& Sheeran, 1998). Cognitive and affective components of attitude are believed to simultaneously account for intentions, although they may have a differential impact on them. Attitude theory researchers have long argued that the relationship between cognition and affect in attitude formation is bidirectional (Johnson \& Grayson, 2005), beginning with cognitive states giving rise to emotions and then emotions shaping cognitive states (Anand, Morris, \& Stephens, 1988; Andersen \& Kumar, 2006; M. Johnson, Hermann, \& Huber, 2006).

In this process, the salience of the affective or the cognitive component could lead to the formation of different intentions (Berg, Manstead, Pligt, \& Wigboldus, 2006). Attitudes that are based on cognition are conceptually distinct from attitudes that are based on affect (Sherman \& Kim, 2002). Affect is expected to increase intrinsic motivation, which refers to the motivation to engage in a behavior for its own sake, out of personal interest and/or enjoyment, and not as a means to another reward (Isen \& Reeve, 2005). Attitudes based on affect tend to persevere despite situational conditions (Zajonc, 1980) or rational decision making (Andersen \& Kumar, 2006). Conversely, cognition involves more calculative considerations and thus is more vulnerable to external incentives and can be more easily invalidated and changed (Zajonc, 1998). Whereas cognition is directly subject to counterargumentation, affect is not easily dislodged (Oliver, 1999). Thus, affect can lead to much stronger behavioral reactions than pure cognition (Zajonc \& Marcus, 1982) and dominates over cognition in the prediction of conative attitudes (French et al., 2005; Godin, 1987).

Moreover, prior research suggests that positive emotions are associated with approach-oriented behavior that leads individuals to perform above and beyond the call of duty (Elliot \& Thrash, 2002; Watson, Wiese, Vaidya, \& Tellegen, 1999). For instance, research in organizational behavior shows that the presence of positive affect predicts behavior that extends beyond a job description (Fisher, 2002; Judge \& Ilies, 2004). This "employee citizenship behavior" (Yi \& Gong, 2008) entails acts involving altruism, extra effort, volunteering, and being cooperative. Furthermore, workers with high positive affect do not typically engage in withdrawal behavior as a response to dissatisfaction in the workplace (Thoresen, Kaplan, Barsky, Warren, \& de Chermont, 2003). Also, social psychology considers that positive affect has beneficial effects on the way in which people perceive social behaviors and the way in which they initiate social interactions (Forgas, 2001; Isen, 1987).

A considerable body of consumer behavior literature has dealt with the attitude-behavior relationship. Perhaps the most popular research is the framework developed by Dick and Basu (1994) in which they make a distinction between attitudinal and behavioral loyalty. Dick and Basu stated that loyalty has two dimensions: relative attitude and repeat patronage behavior. 
They identified four loyalty categories: loyalty (positive relative attitude, high repeat patronage), latent loyalty (positive relative attitude, but low repeat patronage), spurious loyalty (high repeat patronage, low relative attitude), and no loyalty (low on both dimensions). The high patronage of spurious loyal customers may be explained by factors such as habitual buying, financial incentives, convenience, and lack of alternatives. Thus, the behavioral approach may not yield a comprehensive insight into the underlying reasons of loyalty or patronage. Instead it is a consumer's disposition in terms of intentions that plays an important role, and it is possible to understand behavior better by decomposing attitude into its main components.

However, most research considers attitude/disposition as a whole without accounting for attitude's components and drivers (Simonin \& Ruth, 1998), namely emotion, cognition, and intention. This study aims to examine the different components of attitude and explore the impact of different drivers in relationship outcomes and intended consumer behavior.

\section{THE RESEARCH: REASSESSING RELATIONSHIPS IN CONSUMER MARKETS}

The purpose of this study is to explore buyer-seller relationships mainly from the customer's point of view. Customers may not all want or need a relationship, and their potential benefits may not be equally considered worthwhile. In this article, consumer relationship intention refers to the willingness of a consumer to develop a relationship with a firm and reflects attitude, namely cognitions and affective feelings on which the attitude was based. As discussed previously, the establishment of a relationship is signaled not only by behavior but more by the reasons why the behavior occurs (Venetis \& Ghauri, 2004). Given the salience of affective or cognitive reasons, attitude could lead to the formation of different relationship intentions.

The framework proposed (see Figure 1) considers that attitudes based on emotions tend to have a stronger effect on relationship intentions and on the persistence of the relationship. Namely, consumers with a relationship intention based on positive affect would be more likely to enact behaviors that lead to the successful completion of the relationship (Andersen \& Kumar, 2006) or "pro-relationship maintenance acts" (Rusbult, Wieselquist, Foster \& Witcher, 1999), as mentioned in the interpersonal relationship literature. Consumers with high relationship intention would exhibit a reduced propensity to switch provider (e.g., derogation of alternatives), a willingness to make short-term sacrifices (e.g., price increases) for the sake of the relationship, and a willingness to cooperate proactively (e.g., providing feedback) above and beyond the call of duty (e.g., repurchasing). This type of relationship would be "dedication based" (Bendapudi \& Berry, 1997): Consumers develop a relationship with a firm for its own sake, apart from its purely instrumental 


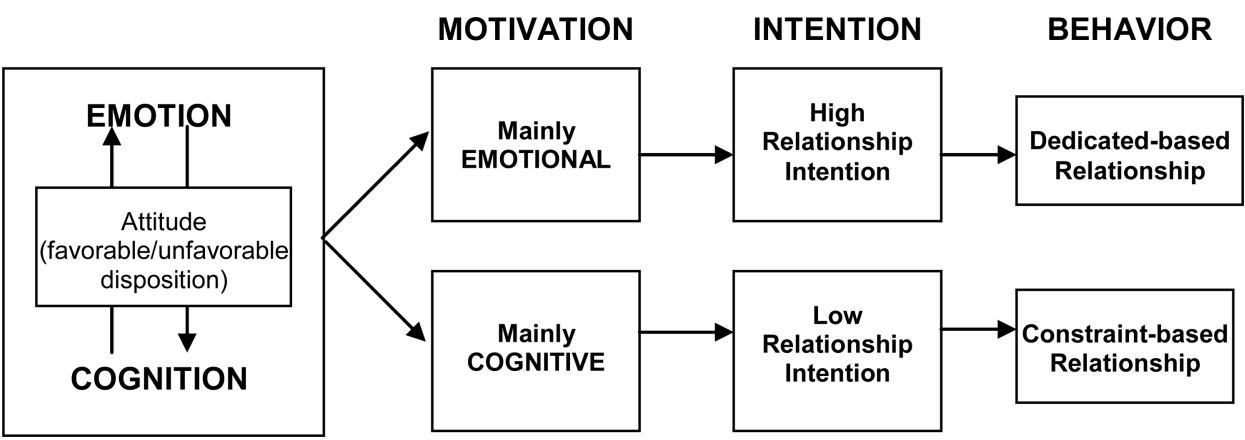

FIGURE 1 Proposed Framework Used to Analyze Differences Between Emotion- and Cognition-Based Relationships.

worth (Gundlach, Achrol, \& Mentzer, 1995). The development of a future dedicated relationship can be determined by this emotional content (Barnes, 1997).

If the cognitive component is more salient in attitude formation, relationships will be highly goal oriented (O'Loughlin \& Szmigin, 2006) and "constraint based" (Bendapudi \& Berry, 1997). Consumers develop a relationship with a firm because they need it on the basis of cost benefit analyses (de Ruyter, Moorman, \& Lemmink, 2001). These "emotionless" consumers (Liljander \& Strandvik, 1996), satisfied but not close (Barnes, 1997), will not invest in the relationship beyond prescribed roles because they make a more conscious evaluation of the rewards and benefits of repatronage. Thus, although these consumers may possess a favorable disposition toward the firm and repurchase a particular product, they will have a low relationship intention (Kumar et al., 2003). Conversely, a customer may not purchase regularly from a firm and still perceive something of a relationship with that firm (Barnes, 1997) in a kind of "latent loyalty" (Dick \& Basu, 1994). These relationships, predicated mostly on the material benefits of the exchange, are likely to suffer from higher turnover, development of alternatives, and opportunistic behavior (Gundlach et al., 1995).

Thus, the relationship formed seems to depend on the degree to which a person willingly intends to engage in it (Kumar et al., 2003; Parish \& Holloway, 2010). Consumers mainly develop relationships either because they want to or because they have to because of some sort of real or perceived constraint (Bendapudi \& Berry, 1997; Odekerken-Schröder \& Bloemer, 2004). We believe that volition plays an important role in the development of relationships (Bejou, 1997), because the more an act toward an object is the result of an individual's free will, the higher the probability that he or she will develop a strong relationship with the object (Bloemer \& Odekerken-Schröder, 2007). We define the willingness to establish a relationship in a free and deliberate way as consumer relationship intention. 
We propose that the degree of this willingness depends on the emotions generated by a particular consumer in the purchase, namely those associated with self-esteem, feelings of affiliation, and social bonding (Dagger \& David, 2012; Eisingerich \& Bell, 2007; Hennig-Thurau et al., 2009; Johnson, Matear, \& Thomson, 2011; Spake, Beatty, Brockman, \& Crutchfield, 2003; Yi \& Gong, 2008). Thus, consumer feelings explain why not all but some consumers value a relational approach. Emotions shape behaviors and perceptions and play a crucial role in the development of different kinds of relationships (Andersen \& Kumar, 2006; Johnson et al., 2006), because these cannot be built on behavior alone (Barnes, 2003). Rather than total rationalizing, customers' behavior is also based on emotional bonds that go beyond core product attributes, involving enjoyment, personal meaning, and a feeling of gratitude, the currency of relationships (Hansen, Sandvik, \& Selnes, 2003; Styles \& Ambler, 2003). Emotional content (Berscheid, Snyder, \& Omoto, 1989) could be the path to attaining true customer intimacy, the backbone of rewarding relationships (Fournier, 1998).

\section{RESEARCH METHODOLOGY}

Our goal is to examine the effect of cognition- and emotion-based consumer motivations on established relationships. We use factor and discriminant analysis to identify which variables are significant contributors to the differences between relationships.

A consumer cross-sectional survey was conducted. The questionnaire was pretested with a group of 36 consumers, who suggested improvements in item wording and directions. Convenience sampling and self-administered surveys were used to collect the data. A total of 384 consumers recruited through a network of acquaintances were invited to participate by accessing a survey Web page. A total of 222 valid returns were obtained, yielding a response rate of 58\%. The resulting sample represented a good cross-section of respondent ages, sexes, and backgrounds; respondents were sufficiently diverse in their use of service providers. The respondent profile was female (55\%), older than 35 years of age (48\%), and holding a bachelor's degree $(44 \%)$.

The design of the questionnaire was based on scales used in previous research and used a 5-point Likert scale, ranging from completely disagree to completely agree. Negative questions were reverse-coded for consistency. Respondents were directed to think about specific firms they patronized and to select one with which they had a satisfying and positive relationship. Respondents were then asked to respond to the remaining questions while focusing on that particular provider. The first section of the survey asked respondents to assess the degree to which several cognition- and emotion-based motivations had been important in their engagement with 
the provider selected. The second section focused on the operationalization of relationship intention and measured five different relationship outcomes based on the behavioral intentions battery commonly referred to in the literature: repurchase intentions, advocacy, switching intentions, acquiescence, and altruism.

The measurement items of the different constructs are shown in Table 1. To measure cognition- and emotion-based motivations, we followed the recommendations of Allen and Meyer (1990), Kumar et al. (2003), Spake et al. (2003), Johnson and Grayson (2005), and Bloemer and OdekerkenSchröder (2007). Behavioral intentions measures were based on Zeithaml, Berry, and Parasuraman (1996), Oliver (1999), Kumar et al. (2003), Bloemer and Odekerken-Schröder (2007), Jones and Taylor (2007), and Eisingerich and Bell (2007).

For each of the constructs measured, dimensionality and reliability were assessed (e.g., Cronbach's alpha). To assess the dimensionality of consumer motivations, we performed a principal component analysis with varimax rotation. It was intuitively expected that the motivations scale would divide into two factors representing cognitive and emotional variables, which it did, with the factors explaining 36\% and $32 \%$ of the variance, respectively. For relationship outcomes, an assessment of eigenvalues and scree plot suggested a five-factor solution (accounting for $76 \%$ of the variance) that appeared to fit well with the initial conceptualization suggested. All scales demonstrated good reliability according to accepted standards. Internal reliability tests of the factors identified showed strong Cronbach's alphas. The scales are reported in Table 1 along with reliability, validity, and dimensionality statistics.

Linear discriminant analysis was used to identify which variables were significant contributors to the differences between the two groups (cognitionand emotion-based relationships). The effective grouping was constructed with the respondents' motivation-generated factor scores as input. Accordingly, each consumer was classified as having either (a) a cognitive relationship or (b) an emotional relationship, with 120 consumers in the first group and 102 consumers in the second group.

\section{DISCUSSION OF RESULTS}

The results led us to conclude that consumer willingness and its motivations are highly significant in discriminating relationship types. Whereas cognitionbased motivations explain more functional outcomes (e.g., repurchase intention), emotion-based motivations explain other manifestations such as altruism, switching intentions, and acquiescence, which may represent higher forms of dedication to the provider. As suggested by Barnes (1997), affective variables contribute the most to the establishment of dedicated and close customer relationships. 
TABLE 1 Measurement Scales, Reliability, Validity, and Dimensionality Statistics

\begin{tabular}{|c|c|c|c|}
\hline Dimension & Measure & PCA Loading & $\alpha(\mathrm{AVE})$ \\
\hline & Dimensions selected for relationship motivations & & \\
\hline Cognition & $\begin{array}{l}\text { I'm a regular and satisfied customer of X } \\
\text { because ... }\end{array}$ & Mean 4.09 & $.87(.638)$ \\
\hline Reliability & ... X keeps promises made & .844 & \\
\hline Perceived value & $\begin{array}{l}\ldots \text { the benefits received more than } \\
\text { compensate the costs associated }\end{array}$ & .820 & \\
\hline Reputation & $\begin{array}{l}\ldots \text { I have good reason to doubt his } \\
\text { competence }(-)\end{array}$ & .638 & \\
\hline Quality & $\ldots X$ offers a high-quality service & .855 & \\
\hline Comfort & $\begin{array}{l}\text {.. of the comfortable relationship I have } \\
\text { established }\end{array}$ & .817 & \\
\hline Emotion & $\begin{array}{l}\text { I'm a regular and satisfied customer of } \mathrm{X} \\
\text { because ... }\end{array}$ & Mean 2.98 & $.88(.658)$ \\
\hline Involvement & ... I feel emotionally attached to $\mathrm{X}$ & .890 & \\
\hline Identification & $\begin{array}{l}\ldots \text { I feel a sense of identification of interests } \\
\text { and values with } X\end{array}$ & .800 & \\
\hline Familiarity & ... I feel like "part of the family" & .891 & \\
\hline Reciprocity & ... I feel X has my best interests at heart & .666 & \\
\hline $\begin{array}{l}\text { Fear of relationship } \\
\text { loss }\end{array}$ & $\begin{array}{l}\ldots \text { I would feel a sense of personal loss if I } \\
\text { could no longer be X's client }\end{array}$ & .790 & \\
\hline
\end{tabular}

Repurchase Intention Repeat purchase

First choice Share of wallet

\section{Advocacy \\ Positive word of mouth}

Recommendation

Encouragement

Switching Intentions Active tracking

Active monitoring

Search for alternatives

Altruism

Cross-selling

Active voice

Willingness to cooperate

Acquiescence

Price insensitivity

Dissatisfaction

response

Tolerance
Dimensions selected for relationship outcomes

I plan to do more business with $\mathrm{X}$ in the next few years

I consider $\mathrm{x}$ to be my first choice

Mean $4.11 \quad .85(.769)$

.876

.872

.882 service

I say positive things about $\mathrm{X}$ to other people

Mean 3.96

.951

I recommend $\mathrm{X}$ to someone who seeks my advice

I encourage friends and relatives to do business with $\mathrm{X}$

I would take my business to a competitor with more attractive prices

I actively monitor X's service quality and price

I proactively monitor for and am receptive to competitive offers

$\mathrm{I}$ intend to buy more and other $\mathrm{X}$ services in the future

Whenever I have a problem, I discuss my complaints with X

I am available to cooperate with $\mathrm{X}$

.976

Mean $2.98 \quad .78(.699)$

.827

.784

.894

Mean $3.63 \quad .70(.620)$

.846

.780

.733

I would continue to do business with $\mathrm{X}$ even if prices increase

I would switch to a competitor if I experience a problem with $\mathrm{X}(-)$

I would continue to do business with $\mathrm{X}$ even if quality decreases
Mean 2.77

.819

.780

.746

Notes: The (-) sign indicates that the question was reverse-coded for consistency. X refers to the service provider selected by each respondent. $\mathrm{PCA}=$ principal component analysis; $\mathrm{AVE}=$ average variance extracted. 
The discriminant function is significant, $\chi^{2}(5)=53.3, p=.000$, Wilks's $\lambda=.782$. Table 2 shows Wilks's lambda and $F$ values, results of tests of equality of group means, significance levels ( $p$ values), and the correlations between each of the five discriminant variables and the discriminant function, expressed through standardized canonical coefficients ordered by their importance.

The discriminant function (see Table 2) shows how proposed variables (relationship outcomes) prove to be significant as discriminators between cognition (functional) or emotion (dedicated) based relationships. The standardized canonical coefficients obtained in the structure matrix indicate the relative importance of each of the five variables considered in differentiating emotional versus cognitive relationships. The structure matrix of the discriminant analysis shows that acquiescence has the greatest influence on the discriminant function, followed by altruism and switching intentions.

TABLE 2 Discriminant Analysis, Tests of Equality of Group Means, and Structure Matrix

\begin{tabular}{lcccr}
\hline Variable & Wilks's $\lambda$ & $F$ & $p$ & Standard Coefficients \\
\hline Acquiescence & .853 & 37.909 & .000 & .787 \\
Altruism & .883 & 29.126 & .000 & .690 \\
Switching Intentions & .901 & 24.298 & .000 & -.630 \\
Advocacy & .921 & 18.870 & .000 & .555 \\
Repurchase Intentions & .962 & 8.679 & .004 & .377 \\
\hline
\end{tabular}

These results seem to demonstrate, as Jones and Taylor (2007) and Kumar et al. (2003) suggested, that more than a favorable disposition, a true relationship (as opposed to a merely functional or transactional one) implies higher order intentions, such as a willingness to make sacrifices (like tolerating higher prices) or altruism (willingness to assist). As with friendships or romantic relationships, customers in a dedicated relationship will develop "pro-relationship maintenance acts" (Jones \& Taylor, 2007) or "citizenship behaviors" (Yi \& Gong, 2008) to sustain a long-term, well-functioning relationship, reaching a state of resilience that allows them to overcome obstacles and avoid considering competitive brands intentionally (Oliver, 1999) and somewhat irrationally. Measures of affect contribute significantly to important dependent variables in consumer behavior (Barnes, 1997). These behaviors (such as acquiescence and altruism), highly differentiating between emotionand cognition-based relationships, would be better indicators of a true relationship. Conversely, behaviors such as advocacy and repurchase intentions, have less predictive power and more likely to be present in both types of relationships.

The classification table generated from this discriminant model correctly classifies $72 \%$ of the respondents. This hit ratio is significantly better than chance, as confirmed in a comparison of the classification accuracy 
to the maximum chance criteria ( $54 \%$ correct assignment) and proportional chance criteria (50\% correct assignment; Hair, Anderson, Tatham, \& Black, 2006).

\section{RESEARCH AND MANAGERIAL CONTRIBUTIONS}

This study makes several theoretical and research contributions. First, it critically examines the nature of buyer-seller relationships in consumer markets and begins to fill the gap in the literature by taking the customer's point of view into consideration. Understanding the reasons why consumers maintain relationships is important, and this study adds to the growing body of evidence on the active role of the consumer. The study acknowledges consumer recognition as the prime driver in a relational approach, a neglected domain of RM, and helps to define relationships in consumer markets, a glaring omission in the literature.

Second, our research identifies consumer relational intention as a key factor in distinguishing different relationships. By considering consumers' willingness to establish a relationship in a deliberate way as an essential prerequisite, this research goes beyond the concept of loyalty. Not just a favorable disposition or a positive attitude toward the firm must be present but also the willingness to invest in a relationship with that firm in a deliberate way.

Finally, this research highlights the importance of emotions in consumer-firm relationships by empirically establishing a distinction between relationships based on their underlying emotional or cognitive motivations. The research draws a comparison between consumer relationships and friendships or romantic relationships, which cannot exist without emotional content. According to our research, consumer investments in relationships tend to be stronger when they are based on emotional content. In emotion-based relationships, customers tend to develop pro-maintenance acts, such as short-term sacrifices (e.g., accepting price increases) or proactive cooperation (e.g., active voice) above and beyond the call of duty. When relationships are functional, consumers make a more conscious evaluation of the rewards and benefits of repatronage. Though satisfied, they will not invest beyond the status quo. Relationship outcomes such as acquiescence, altruism, and switching intentions seem to characterize truly relational and dedicated clients.

On a managerial level, firms can adjust their relational efforts based on the results of our research. These efforts need to be tempered by the customers' willingness to develop a relationship. Segmenting the customer base of an organization into low and high relational groups would allow firms to target those customers inclined to engage in relationships instead of wasting resources on targeting unwilling customers. High relationship 
intention should be measured along with attitudes and intentions instead of behaviors commonly tracked and rewarded by firms, such as repurchase behavior. In fact, outcomes such as acquiescence and altruism seem to be more effective in identifying high relational customers. Managers need to seek a greater understanding of these consumer differences in order to better manage customer relationships. Furthermore, given the finding that emotion and cognition motivation discriminate high and low relationship intentions, firms should consider strategies that would increase the perception of emotional content (e.g., personal contact and social bonding) in order to reap larger benefits from highly relational customers.

\section{LIMITATIONS AND FUTURE RESEARCH}

This study is not without its limitations. First, considering the nature of this study, the findings reported are descriptive rather than confirmatory. Replication of this study with random sampling procedures would add weight to the reported results. Second, further research using a longitudinal design could better address relationship dynamics. Third, we only examined consumers with favorable dispositions toward a firm. Analysis of the effect of negative attitudes would require further research. This study could also be improved by including data on customers' actual behavior history, as measurements were based on self-report. In addition, a number of contextual factors not investigated here may prove to be significant in future studies, such as gender and other consumer characteristics, or service provider type and the nature of the product/market/firm, as suggested by, for example, Grönroos (1991).

\section{CONCLUSION}

This article shows the importance of consumer proneness and its motivations in the development of a relational approach in buyer-seller relationships in B2C settings. We have presented empirical research to highlight the fact that consumers' relationships may be different according to their cognitive or emotional motivations. Linear discriminant analysis was used to identify which variables are significant contributors to differences between the two groups. We found that cognition-based motivations explain functional relationship outcomes and that emotion-based motivations explain higher forms of dedication to the provider, such as altruism, switching intentions, and acquiescence. By taking the customer's point of view into consideration rather than focusing solely on context conditions or seller perceptions, this study fills a gap in the literature on buyer-seller relationships. We show that consumer relationship intention and motivations are highly significant in discriminating relationships. 


\section{REFERENCES}

Agariya, A., \& Singh, D. (2011). What really defines relationship marketing? A review of definitions and general and sector-specific defining constructs. Journal of Relationship Marketing, 10(4), 203-237.

Ajzen, I., \& Fishbein, M. (1980). Understanding attitudes and predicting social behavior. Englewood Cliffs, NJ: Prentice Hall.

Allen, J., \& Meyer, J. (1990). The measurement and antecedents of affective, continuance and normative commitment to the organization. Journal of Occupational Psychology, 63, 1-18.

Anand, P., Morris, B., \& Stephens, D. (1988). The formation of affective judgments: The cognitive-affective model versus the independence hypothesis. Journal of Consumer Research, 15, 386-391.

Andersen, P., \& Kumar, R. (2006). Emotions, trust and relationship development in business relationships: A conceptual model for buyer-seller dyads. Industrial Marketing Management, 35, 522-535.

Bagozzi, R. (1995). Reflections on relationship marketing in consumer markets. Journal of the Academy of Marketing Science, 23(4), 272-277.

Bagozzi, R., \& Burnkrant, R. (1979). Attitude measurement and behavior change: A reconsideration of attitude organization and its relationship to behavior. $A d-$ vances in Consumer Research, 6, 295-302.

Barnes, J. (1997). Closeness, strength, and satisfaction: Examining the nature of relationships between providers of financial services and their retail customers. Psychology and Marketing, 14, 765-790.

Barnes, J. (2003). Establishing meaningful customer relationships: Why some companies and brands mean more to their customers. Managing Service Quality, 13(3), 178-186.

Bejou, D. (1997). Relationship marketing: Evolution, present state and future. Psychology and Marketing, 14, 727-736.

Bendapudi, N., \& Berry, L. (1997). Customer's motivation for maintaining relationships with service providers. Journal of Retailing, 73(1), 15-37.

Berg, H., Manstead, A., Pligt, J., \& Wigboldus, W. (2006). The impact of affective and cognitive focus on attitude formation. Journal of Experimental Social Psychology, 42, 373-379.

Berscheid, E., Snyder, M., \& Omoto, A. (1989). Issues in studying close relationships: Conceptualising and measuring closeness. In C. Hendrick (Ed.), Review of personality and social psychology (Vol. 10, pp. 63-91). Newbury Park, CA: Sage.

Bloemer, J., \& Odekerken-Schröder, G. (2007). The psychological antecedents of enduring customer relationships: An empirical study in a bank setting. Journal of Relationship Marketing, 6(1), 21-43.

Blois, K. (1997). When is a relationship "a relationship"? In H. Gemuden, T. Ritter, and A. Walter (Eds.). Relationships and networks in international markets (pp. 53-64). Oxford, UK: Elsevier Science.

Blois, K. (2003). B2B "relationships"-A social construction of reality? Marketing Theory, 3(1), 79-95. 
Breckler, S. (1984). Empirical validation of affect, behavior and cognition as distinct components of attitude. Journal of Personality and Social Psychology, 47, 1191-1205.

Breckler, S., \& Wiggins, E. (1989). Affect versus evaluation in the structure of attitudes. Journal of Experimental Social Psychology, 25, 253-271.

Christy, R., Oliver, G., \& Penn, J. (1996). Relationship marketing in consumer markets. Journal of Marketing Management, 12(1/3), 175-187.

Dagger, T., \& David, M. (2012). Uncovering the real effect of switching costs on the satisfaction-loyalty association: The critical role of involvement and relationship benefits. European Journal of Marketing, 46(3/4), 447-468.

de Ruyter, K., Moorman, L., \& Lemmink, J. (2001). Antecedents of commitment and trust in customer-supplier relationships in high technology markets. Industrial Marketing Management, 30, 271-286.

De Wulf, K., Odekerken-Schröder, G., \& Iacobucci, D. (2001). Investments in consumer relationships: A cross-country and cross-industry exploration. Journal of Marketing, 65, 33-50.

Dick, A., \& Basu, K. (1994). Customer loyalty: Toward an integrated conceptual framework. Journal of the Academy of Marketing Science, 22(2), 99-113.

Dwyer, F., Shurr, P., \& Oh, S. (1987). Developing buyer seller relations. Journal of Marketing, 51(2), 11-28.

Egan, J. (2000). Drivers to relational strategies in retailing. International Journal of Retail \& Distribution Management, 28(8), 379-386.

Egan, J. (2003). Back to the future: Divergence in relationship marketing research. Marketing Theory, 3(1), 145-157.

Egan, J., \& Harker, M. (2006). The past, present and future of relationship marketing. Journal of Marketing Management, 22(1), 215-242.

Eisingerich, A., \& Bell, S. (2007). Maintaining customer relationships in high credence services. Journal of Services Marketing, 21(4), 253-262.

Elliot, A., \& Thrash, T. (2002). Approach-avoidance motivation in personality: Approach and avoidance temperaments and goals. Journal of Personality and Social Psychology, 82, 804-818.

Emmons, R. (1986). Personal strivings: An approach to personality and subjective well-being. Journal of Personality and Social Psychology, 51, 10581068.

Fernandes, T., \& Proença, J. (2008). The blind spot of relationships in consumer markets. Journal of Marketing Management, 24(1/2), 153-168.

Fishbein, M., \& Ajzen, I. (1975). Belief, attitude intention and behavior: An introduction to theory and research. Reading, MA: Addison-Wesley.

Fisher, C. (2002). Antecedents and consequences of real-time affective reactions at work. Motivation and Emotion, 26, 3-30.

Ford, D. (2004). Guest editorial-The IMP Group and international marketing. International Marketing Review, 21(2), 139-141.

Forgas, J. (2001). The handbook of affect and social cognition. Mahwah, NJ: Erlbaum.

Fournier, S. (1998). Consumers and their brands: Developing relationship theory in consumer research. Journal of Consumer Research, 24(4), 343-373.

Fournier, S., Dobscha, S., \& Mick, D. (1998). Preventing the premature death of relationship marketing. Harvard Business Review, 76, 42-51. 
French, D., Sutton, S., Hennings, S., Mitchell, J., Wareham, N., Griffin, S., ... Kinmonth, A. (2005). The importance of affective beliefs and attitudes in the theory of planned behavior: Predicting intention to increase physical activity. Journal of Applied Social Psychology, 35, 1824-1848.

Godin, G. (1987). Importance of the emotional aspect of attitude to predict intention. Psychological Reports, 61, 719-723.

Grayson, K., \& Ambler, T. (1999). The dark side of long-term relationships in marketing services. Journal of Marketing Research, 36(1), 132-142.

Grönroos, C. (1991). The marketing strategy continuum: Toward a marketing concept for the 1990s. Management Decision, 29(1), 7-13.

Gundlach, G., Achrol, R., \& Mentzer, J. (1995). The structure of commitment in exchange. Journal of Marketing, 59(1), 78-92.

Hakansson, H., \& Snehota, I. (2002). The burden of relationships or who's next? In D. Ford (Eds.), Understanding business markets (pp. 88-94). London, England: Thompson Learning.

Hair, J., Anderson, R., Tatham, R., \& Black, W. (2006). Multivariate data analysis. New York, NY: Prentice Hall.

Hansen, H., Sandvik, K., \& Selnes, F. (2003). Direct and indirect effects of commitment to a service employee on the intention to stay. Journal of Service Research, 5(4), 356-368.

Hansen, T. (2012). The moderating influence of broad-scope trust on customer-seller relationships. Psychology \& Marketing, 29(5), 350-364.

Hellén, K., Gummerus, J., Grönroos, C., \& Sääksjärvi, M. (2007). Love at first sight or a long-term affair? Journal of Relationship Marketing, 6(1), 45-61.

Hennig-Thurau, T., Gwinner, K., \& Gremler, D. (2002). Understanding relationship marketing outcomes: An integration of relational benefits and relationship quality. Journal of Service Research, 4(3), 230-247.

Hennig-Thurau, T., Paul, M., Gremler, D., Gwinner, K., \& Weitz, C. (2009). Towards a theory of repeat purchase drivers for consumer services. Journal of the Academy of Marketing Science, 37, 215-237.

Isen, A. (1987). Positive affect, cognitive processes and social behaviour. In L. Berkowitz (Ed.), Advances in experimental social psychology (Vol. 20, pp. 203-253). New York, NY: Academic Press.

Isen, A., \& Reeve, J. (2005). The influence of positive affect on intrinsic and extrinsic motivation: Facilitating enjoyment of play, responsible work behavior, and selfcontrol. Motivation and Emotion, 29(4), 295-323.

Johnson, A., Matear, M., \& Thomson, M. (2011). A coal in the heart: Self-relevance as a post-exit predictor of consumer anti-brand actions. Journal of Consumer Research, 38, 108-125.

Johnson, D., \& Grayson, K. (2005). Cognitive and affective trust in service relationships. Journal of Business Research, 58, 500-507.

Johnson, M., Hermann, A., \& Huber, F. (2006). The evolution of loyalty intentions. Journal of Marketing, 70, 122-132.

Jones, T., \& Taylor, S. (2007). The conceptual domain of service loyalty: How many dimensions? Journal of Services Marketing, 21(1), 36-51.

Judge, T., \& Ilies, R. (2004). Affect and job satisfaction: A study of their relationship at work and at home. Journal of Applied Psychology, 4, 661-673. 
Kumar, V., Bohling, T., \& Ladda, R. (2003). Antecedents and consequences of relationship intention: Implications for transaction and relationship marketing. Industrial Marketing Management, 32, 667-876.

Liljander, V., \& Strandvik, T. (1996). The nature of relationship quality. In D. Carson \& A. Gilmore (Eds.), Services marketing-Texts and readings (pp. 255-270). Dublin, Ireland: Mercury.

Möller, K., \& Halinen, A. (2000). Relationship marketing theory: Its roots and directions. Journal of Marketing Management, 16, 29-54.

Noble, S., \& Phillips, J. (2004). Relationship hindrance: Why would consumers not want a relationship with a retailer? Journal of Retailing, 80, 289-303.

Odekerken-Schröder, G., \& Bloemer, J. (2004). Constraints and dedication as drivers for relationship commitment: An empirical study in a health-care context. Journal of Relationship Marketing, 3(1), 35-52.

Oliver, R. (1999). Whence consumer loyalty? Journal of Marketing, 63, 33-44.

O'Loughlin, D., \& Szmigin, I. (2006). Emerging perspectives on customer relationships, interactions and loyalty in Irish retail financial services. Journal of Consumer Behavior, 5(2), 117-129.

O’Malley, L., \& Tynan, C. (2000). Relationship marketing in consumer markets: Rhetoric or reality? European Journal of Marketing, 3, 797-815.

Palmer, R. (2007). The transaction-relational continuum: Conceptually elegant but empirically denied. Journal of Business and Industrial Marketing, 22(7), 439-451.

Parish, J., \& Holloway, B. (2010). Consumer relationship proneness: A reexamination and extension across service exchanges. Journal of Services Marketing, 24(10), $61-73$.

Pels, J. (1999). Exchange relationships in consumer markets? European Journal of Marketing, 33(1/2), 19-37.

Pressey, A., \& Mathews, B. (2000). Barriers to relationship marketing in consumer retailing. Journal of Services Marketing, 14(3), 272-286.

Rogers, R., \& Thistlethwaite, D. (1970). Effects of fear arousal and reassurance on attitude change. Journal of Personality and Social Psychology, 15, 227-233.

Rusbult, C., Wieselquist, J., Foster, C., \& Witcher, B. (1999). Commitment and trust in close relationships. In J. M. Adams \& W. H. Jones (Eds.), Handbook of interpersonal commitment and relationship stability (pp. 427-449). New York, NY: Kluwer Academic.

Sherman, D., \& Kim, H. (2002). Affective perseverance: The resistance of affect to cognitive invalidation. Personality and Social Psychology Bulletin, 28(2), 224-237.

Sheth, J., \& Parvatiyar, A. (1995). Relationship marketing in consumer markets: Antecedents and consequences. Journal of the Academy of Marketing Science, 23(4), 255-271.

Shrivastava, S., \& Kale, S. (2003). Philosophising on the elusiveness of relationship marketing theory in consumer markets: A case for reassessing ontological and epistemological assumptions. Australasian Marketing Journal, 11(3), 61-72.

Simonin, B., \& Ruth, J. (1998). Is a company known by the company it keeps? Assessing the spillover effects of brand alliances on consumer brand attitudes. Journal of Marketing Research, 35(1), 30-42. 
Spake, D., Beatty, S., Brockman, B., \& Crutchfield, T. (2003). Consumer comfort in service relationships: Measurement and importance. Journal of Service Research, 5(4), 316-332.

Styles, C., \& Ambler, T. (2003). The coexistence of transaction and relational marketing: Insights from the Chinese business context. Industrial Marketing Management, 32, 633-642.

Szmigin, I., \& Bourne, H. (1998). Consumer equity in relationship marketing. Journal of Consumer Marketing, 15, 544-557.

Thoresen, C., Kaplan, S., Barsky, A., Warren, C., \& de Chermont, K. (2003). The affective underpinnings or job perceptions and attitudes: A meta-analytic review and integration. Psychological Bulletin, 129, 914-945.

Trafimow, D., \& Sheeran, P. (1998). Some tests of the distinction between cognitive and affective beliefs. Journal of Experimental Social Psychology, 34, 378-397.

Tynan, C. (1997). A review of the marriage analogy in relationship marketing. Journal of Marketing Management, 13, 695-703.

Venetis, K., \& Ghauri, P. (2004). Service quality and customer retention: Building long term relationships. European Journal of Marketing, 38, 1577-1598.

Warner, L., \& DeFleur, M. (1969). Attitude as an interactional concept: Social constraint and social distance as intervening variables between attitudes and action. American Psychological Review, 34, 153-169.

Watson, D., Wiese, D., Vaidya, J., \& Tellegen, A. (1999). The two general activation systems of affect: Structural findings, evolutionary considerations, and psychobiological evidence. Journal of Personality and Social Psychology, 76, 820-838.

Wetzels, M., de Ruyter, K., \& Birgelen, M. (1998). Marketing service relationships: The role of commitment. Journal of Business and Industrial Marketing, 13, 406-423.

Yi, Y., \& Gong, T. (2008). If employees "go the extra mile," do customers reciprocate with similar behavior? Psychology \& Marketing, 25, 961-986.

Zajonc, R. (1980). Feeling and thinking: Preferences need no inferences. American Psychologist, 35, 151-175.

Zajonc, R. (1998). Emotions. In D. T. Gilbert, S. T. Fiske, \& G. Lindzey (Eds.), The handbook of social psychology (4th ed., Vol. 2, pp. 591-632). Boston, MA: McGraw-Hill.

Zajonc, R., \& Marcus, H. (1982). Affective and cognitive factors in preferences. Journal of Consumer Research, 9, 123-131.

Zeithaml, V., Berry, L., \& Parasuraman, A. (1996). The behavioral consequences of service quality. Journal of Marketing, 60, 31-46.

Zolkiewski, J. (2004). Relationships are not ubiquitous in marketing. European Journal of Marketing, 38(1/2), 24-29. 